\title{
AN ENQUIRY ON FISH SELLING CULTURE AT SOUTH SUMATERA: INVESTIGATION FROM ISLAMIC PERSPECTIVE
}

\author{
Reno Juwarno \\ Faculty of Islamic Studies, Universitas Muhammadiyah \\ Surakarta \\ email: multazam.reno@yahoo.co.id
}

\section{ABSTRACT}

The diversity in Indonesia makes each region having their model of live, behavior and the mode of transactions. South Sumatera is one of those regions that have been practicing a way of fish sale which is different from others. Fish is sold directly from a pit underneath water flow called lebung through an auction model. This different model of regular sale and auction evokes curiosity as to whether it conforms to shariah requirements or not. The purpose of this research is to investigate the habitual transaction of fish sale in this region. This paper will focus on the practice of people at Seri Kembang I village about the sale by carrying out qualitative approach in a field research involving observation, interview and documentation as the means for collecting data. All data collected will be analyzed through evaluation process by comparing the practice over the actual standard. We conclude that such practice is deemed to be non-permissible since it does not pass some of the standards, especially the garar element. We also provide some suggestion as the alternative of this habitual practice.

Keywords: Lebung, garar, Indonesia, Fish Sale

\section{INTRODUCTION}

Indonesia is a multi-culture country with 261 million of its citizen living in a separated place and various islands. The way 
of conduct in each region is highly different to the extent that two neighboring places might have different language (not to say dialect), preferable type of food, marriage custom, celebration days and many others. It is close to what we typically observe of the European countries which the member of it differs from one to another. As the distinctness of the cultures reaches many aspects of life, the manner of people selling and buying in some areas is different from others.

It is South Sumatera, one of Indonesian province, which has that type of different manner in sale, specifically for fish commodity. South Sumatera which prior to 1983 was governed by the classical type of inhabitant's governance called Marga has been changed into a modern type of administration by the establishment of a province in exchange of Marga. Marga afterwards become an autonomy body within South Sumatera Province which stands independently from country's structural body. Thus, it has no revenue post from government meanwhile the obligation to pay its employee still remains. Marga has to recourse on exploiting their authorized land, one of which is by the way of selling fish with specific method called termed as fish selling in "lebung"

The practice of fish selling in lebung is not only done by marga, but also has been practiced widely by citizen. While the ordinary fish selling can be found at the market, some people prefer to buy it from lebung auction. This widespread model of fish selling becomes norm lately and no people questioning regarding its conformity towards shariah standard for sale.

Lebung itself is a pit underneath a river, canal or any water channel whether it is naturally existed or artificially made by 
human. Fishes within lebung would then be sold to the people through auction model. Before dealing the auction, buyer will make rough investigation on the fishes within lebung by catching it using fishnet. The price agreement is determined by this rough investigation and according to the wide of the lebung. This kind of selling has no clarity in the characteristic of the subject matters (i.e. the fish) since rough investigation which is done prior to make the dealing is highly possible to be misleading.

Islam puts big concern in buying and selling by emphasizing that the contract has to be done in fair manner. Not knowing the subject matter in a contract will lead into unfair condition in which one of the party will borne the lose. Thus, investigation on shariah conformity for the type of fish selling described above is important to enlighten people on how shall they conduct the fish selling according to the shariah principle. This in addition that selling fish within lebung is one of main business to which people lay their life upon it.

This research will investigate the practice of South Sumatera people in selling fish within lebung, specifically at Seri Kembang I village, Ogan Ilir region. Using the qualitative approach for a field research, there will be three types of methods to collect the data needed, which are observation, interview and documentation. Evaluation technique will be carried out to produce the result. Thus, this paper will start with some literature review to show some previous related researches in the same field. The next session will be theoretical underpinning which will be used as the standard of shariah investigation. Data and methodology will be presented after it, continued by elaborating the discussion and result at the following session. 


\section{LITERATURE REVIEW}

The diverse culture in Indonesia results in many types and manners in selling. Each region has its uniqueness. A village in Lamongan for instance, there is a practice of fish selling by the way of tebas. This tebas model is done by determining the lower and higher price based on the length and width of the pool. The auction comes next in which the price cannot be lower then the minimum price and must not exceed the upper limit. The next step uses lottery to decide the winner of the auction since in many cases there are number of buyers who agree on the same price. $\mathrm{Na}$ 'imah (2012) in his research concludes that there is no clarity over subject matter in such dealing. That is because the fishes are still inside the pool. Besides of that, the fishes actually come naturally to the pool and neither nurture nor breeding is needed. However, the research concludes that the vagueness of subject matter is eliminated by showing evidences of subject matters by seller and buyer. Thus, this kind of selling is shariah compliant.

Another type of fish selling model is found at a village in Sleman. Here, the selling is done through fishing with a limited time in an agreed pool. The subject matter which is fish is observed roughly prior of fishing to know the approximate quantity within the pool. The observation is of course based on the experience of the buyer. The price is determined here based on the time agreed and approximate quantity of fishes. However, the buyer can only take all the fishes if he is able to catch all of it in a given time agreed before. This type of selling seems to have no clear subject matter (garar) that could make the selling being prohibited. However, Nurudin (2009) in his research finds this type of fish selling is permissible since it fulfils all the pillars of buying and selling in Islam. Apart of it, he gives some notes in the 
end of his research which emphasizes the transparency from both parties and more thorough investigation from buyer part when quantifying the fishes within the pool.

In addition to that, Yudianto (2015) also did a research on how fisherman at Rembang typically sells their fish. It is found that the middleman tends to be superior in determining the price so that results in forced condition for the fisherman part. Besides, there is found indication on fraudulent exercise in measurement process. Based on those facts, the conclusion of the research states that this type of sale is not shariah compliant and thus prohibited.

Based on some papers above, the research will be conducted here has some differences. First, this research focuses on Islamic perspective of fish selling inside lebung with the auction model as the object of investigation. Second, the place in which this research conducted is Seri Kembang I village which makes it different from the previous papers. Therefore this research is believed to be the new for the specific object and place mentioned.

\section{THEORETICAL UNDERPINNING}

\section{The Concept of Sale}

The discussion on sale must be concerning on its validity, while the validity itself goes back to fulfillment of its pillar when the sale conducted. Selling fish inside lembung is type of sale that becomes debatable for the vagueness of the pillars. Thus, deep understanding on the pillars of sale must be elaborated well in order to measure the compliance of fish sale inside lembung. The pillars explained here will be the basic for the assessment later in the discussion part of this paper.

There are four main pillars in sale, according to majority of scholars. The pillars have specific conditions that must be fulfilled 
in order to make a sale shariah compliant (Hasan, 2003). The four pillars are:

1. The contracting parties (buyer and seller)

2. Subject matter (the commodity)

3. The price (anything that will be exchanged with the commodity of subject matter)

4. Statement of contract (shighah)

Within those pillars, there are some conditions:

1. Conditions for the contracting parties

The contracting parties must be sane ('aqil), able to distinguish the right from the wrong (mumayyiz), mukhayyar or having freedom of its action (Afandi, 2009). Thus, the contract of an insane person, drunk, a child and people under forced situation is invalid. The contract of a children will be dependent on the permission of their parents (Sabiq, 2011).

2. Conditions for subject matter

a. The purity of subject matter.

The subject matter must not contain najasah (unclean substance from shariah perspective) and must not be prohibited by shariah. Thus, the sale of wine, pork and sort of those things are not allowed.

b. Usefulness aspect of the subject matter.

The subject matter transacted must be useful and such selling of the cockroach, ants or other things are not allowed unless the usefulness can be justified.

c. Possession of the subject matter

The subject matter must be possessed by the contracting parties or by the permission of its owner. 
d. Deliverability of the subject matter

The transacted subject matter can be delivered to the right holder of the commodity after transaction.

e. Subject matter is known to both parties

The contracting parties must know the subject matter when involving into the dealing, whether by direct view, knowing the criteria or other way of it. Dealing on an unclear subject matter attracts people to make speculation of getting more even though the possibility of getting less is the same. This could lead into dispute and make clash within society.

3. Conditions for the price.

a. The agreed price has to be determined clearly

b. The price has to be delivered during contract. In case the price is paid by credit, the maturity has to be agreed and clearly determined.

c. In case the transaction is done by barter exchange, the conditions of riba will be applied. It is prohibited to exchange same type of ribawi items unless by the same quantity in cash. When the type of ribawi items is different exchanging by the different quantity is allowed, but has to be in cash. However, when the exchanged items are between ribawi and non-ribawi item, no riba rule is applied (Harun, 2015).

4. Conditions of statement of contract (offer and acceptance).

a. Clarity of both statements.

b. Conformity of both statements.

c. Connection of acceptance with offer. This condition 
refers to the connection of majlis. Thus, the connection of offer and acceptance could be occurred within same physical or virtual place.

d. The firmness of both statements. In the Arabic context, the firmness can be shown by using past tense. However, this might be different from one country to another.

\section{The Concept of Garar}

In addition to the knowledge on the pillars of sale, the case discussed in this paper necessitates understanding about the concept of garar. This is because from what can people observe roughly there might contain garar during the process of sale. Garar literally means risk or faking. It technically means a type of commercial exchange, including sale, which contains jahalah (less knowledge of subject matter) and uncertainty (Azhim A, 2011). This includes the possible inability of delivering subject matter, unclear characteristic of the subject matter itself. Some jurists also defines it as a sale that its legal implication is doubtful (Tarmizi, 2017). In operational sense, garar can be occurred when two contracting parties has no certainty upon the subject matter they are going to deal it, whether its quality, quantity, and delivery time which lead into harm for one side (Karim, 2015).

There are some conditions for a sale to be concluded as prohibited due to its garar characteristic. A garar sale is when a sale has one or more conditions below (Tarmizi, 2017):

1. The garar is excessive in a contract.

Jurists differentiate two types of garar according to its level (portion). First is the excessive garar while the second is the light garar. The excessive garar is defined by Abu Walid Al Baji as 
something that frequently occurs which makes people consider it as the part of the sale. In a simple word, excessive garar is type that can be avoided. This type of garar might appear in various form depends on the situation and place. Thus, the measurement of the garar is referred back to the custom of that place ('urf). When the market custom views the conduct as an excessive garar, then shariah will judge it as excessive as well. For example, selling a watermelon which still in growing process has excessive garar since the watermelon might grow or not.

The light garar is the unavoidable uncertainty within the contract so that no parties will be harmed. For example, buying a house without seeing its foundation has unavoidable garar. This is because seeing the foundation is clearly not doable. Islam provides relaxation for this type of garar and thus making the contract allowed. Thus, the allowable garar is the light one, while the excessive is prohibited (Tarmizi, 2017).

2. The garar happens in the core contract.

The garar becomes prohibited when it is found in the core contract. Meanwhile, the garar in a complementary contract does not invalidate the contract as a whole. A legal maxim pertaining this matter says, "Things can be relaxed in a complementary contract, while it is not in others." This maxim means shariah provides relief when only when the garar occurs on the complementary contract, while it cannot be relaxed in the core one (Arfan, 2013). For example, someone sells crop which does not appear its fruit. If the sale concerns on the fruit itself, then this transaction is broken for the garar element (possibility of the fruit not to ripe) inside it. However, if the concern is sale of the tree of fruit, any 
garar arises on the fruit produced by that tree will not be counted for making invalidity of the contract. This is because the fruit is complementary and not as the core contract (Karim, 2015).

3. There is no authentic need (hajat syar' $i$ ) for the contract.

The authentic need is a state when everybody is estimated to encounter hardship by not engaging on that garar activity. The need itself has to be clear as no other recourse can be utilized except that garar contract such as using conventional insurance as long as the Islamic one is provided in that region. However, when Islamic insurance exists, then the permissibility of using conventional insurance is replaced. This confirms with the legal maxim which says, "A need (hajah) takes the position of primary need (dharurah) whether it is general or specific."

It is also mentioned by Imam Nawawi, the prominent jurist of Syafii mazhab, that when the contract which contains garar is important in the daily life which might cause hardship upon its prohibition, it makes the contract permissible. Ibnu Taimiyah also said that the harm of garar is below the level created by riba and thus can be given relief in case the contract is needed by vast number of citizen. This is because the prohibition of such makes bigger harm (Tarmizi, 2017).

4. The garar happens in commercial contract

Garar is counted as making contract invalid when the type of contract is for commercial purpose. Thus, garar does not apply in charity contracts such as sadaqah, hibah, waqf and sort of those things. The reason is because no party is harmed for the injustice arises from garar in social contract, and thus will not lead into any dispute. This concept confirms the purpose of both commercial 
and charity contract where in the initial both parties demand the exchanged commodity as it is prescribed and expected whether it is in the form of commodity or profit. Meanwhile, the case is different for the latter as the recipient of any charity has no right to demand anything in the first place (Karim, 2015).

\section{The Concept of Auction Sale}

The sale according to its price is classified into many types, one of which is called auction. In the book of fiqh or hadith, this type of sale is termed as bai' al muzayadah (sale with the increment of price), dalalah or munadah. It is defined on those books as a sale when the seller offers his commodity in a market while the buyers competes each other by increasing the price they agree. The commodity then sold to the highest bid of price.

Auction is allowed in Islam as we can understand from a hadith narrated by Abu Daud. The content of the hadith states that Rasul did during his life auction by himself. It is why the majority of jurists opine that auction is allowed except AlNakha'I who said that auction is makruh. Meanwhile, Hasan Al-Bashri, Ibnu Sirin and Auza'I opines that auction is makruh unless on inheritance and booty properties (Ath-Thayyar, 2015). It is important to be noted that the price increment in auction is not regarded as riba since the increase is in the offer of the price from the seller perspective, or in the acceptance price from the buyer perspective (Rusyd, 1992). The increase in the riba is for the exchange of nothing, while the increase in auction is based on the supply-demand pull on the price.

Just like the other contracts, Islam also gives guideline and criteria to prevent any deviation, violation of right, norms and ethics during the sale. In general, the pillar of auction is similar 
with the general sale. Some conditions that might be relevant to be highlighted again are the following:

1. The transaction must be done by those who acquire legal capability and based on consent from both parties.

2. The subject matter must be halal and useful.

3. Total possession and authority on the subject matter.

4. Clarity and transparency over the subject matter of auction without any manipulation.

5. Ability to deliver the subject matter to the buyer.

6. Clarity and transparency over the price without any possibility of further dispute.

7. The auction is done with no collusion or bribe to win the bid.

\section{METHODOLOGY AND DATA DESCRIPTION}

\section{Methodology}

This paper is a type of field research that is a direct research in the field or daily life to know what actually happens (Nasehudin and Gozali, 2012). Qualitative method is used to come into the solution. The data is collected using various methods. First is observation method that is a type of direct or indirect observation to acquire the data (Satori and Komariah, 2013). The purpose is to get valid data as source of analysis. The second is interview which is conducted with any involved party of sale fish inside lembung, including villagers, public figure as well as seller and buyer of fish sale inside lembung at Seri Kembang village I. The expected result from this interview is to know deeper on the practice of this particular sale. The third method used is documentation by collecting any physical documentary such as rules, activity report and other relevant sources (Ridwan, 2010). After collecting all the data, we will conduct the analysis using evaluation technique, 
that is by comparing the practice of fish sale inside lebung in Seri Kembang I village described on the data description part below and the shariah parameter described on the theoretical part above.

\section{Data Description}

This research takes the observation data particularly at Seri Kembang I village at Ogan Ilir district, South Sumatera Province Indonesia. This village is characterized by the upper hill land with the landscape constituted of agriculture land, villager area and swamps. Most of its inhabitant works as farmer for their main livelihood with the addition as trader, fisherman and some other profession. People at Ogan Ilir practiced the sale of fish inside lebung since long time ago. It can be said that this practice has been the culture of people inhabit this area.

Lebung itself is a pit underneath a river, canal or any water channel whether it is naturally existed or artificially made by human. The lebung has many sizes, from big one to the small. The big lebung is usually possessed by the local authority in such they have full right of doing auction for fishes within it. Meanwhile, the small lebung is does not come under the possession of local authority and thus any people who appears to have that lebung within his area of land acquire the right to do the auction. ${ }^{1}$ In general, Ogan Ilir has many lebung so that its fish source is quite abundant, this include in the area of Seri Kembang I village. There are at least 4 lebung at the village: lebung tengah pematang, batang ari rengas, batang ari lubuk bandong, batang ari betong. ${ }^{2}$

Usually the artificial lebung dug on the land of particular person where during the rainy season the volume of that lebung

${ }^{1}$ Based on interview with Mr. Kurai, a buyer from Seri Kembang II village.

${ }^{2}$ Based on interview with Mr. Lakoni, citizen of Seri Kembang I village. 
will raise up. During that rainy season, fishes are allowed to enter from the main river to the lebung. When it comes to the dry season where the water began to dry or decrease, the river mouth will be closed so that the fish will be trapped and can not get out of the lebung.

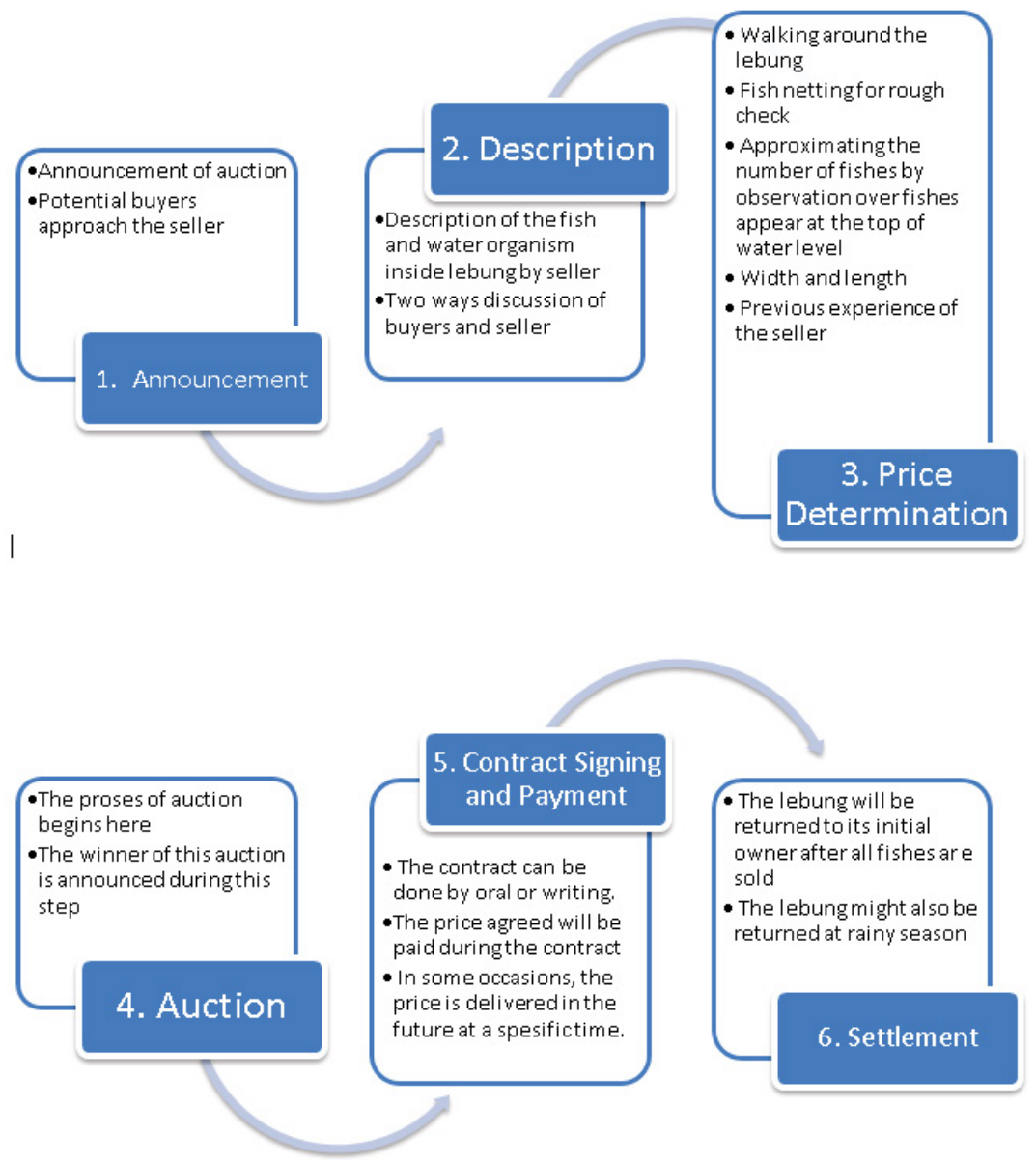

The lebung then will be traded to the public using auction system. In this moment, those who have occupation of selling fish will approach the lebung owner to buy it. The seller himself 
may announce to public that the lebung will be sold. The seller does it whether by verbal announcement or visual (leaflet). The buyer of this auction could be individual, group of people or legal body. ${ }^{3}$ The object of this sale is fish and water organism (all creatures which inhabit at water to live and reproduce) within the lebung. There are many types of fishes that usually captured inside the lebung. It is also important to be noted that there is no any breeding process. All fishes come naturally from the river.

Pertaining to the price determination, it goes back to the auction agreement between seller and all bidders. Seller initially gives standard price for the auction to start. Prior to that, seller describes the approximate condition about the fishes and water organism inside the lebung he wants to sell. The description is not a one-side, it is rather from both side. Buyer asks the seller about the lebung while walking around lebung area followed by rough checking using net by the buyer himself. In addition to it, buyer will observe the fishes which appear at the top level of water. The width and length also can be determinant factor of the price. Apart from it, previous experience of the buyer will help to make more exact approximation. After all those steps, the auction starts until the winner is decided. The auction can be done in private or for public.

Once the winner is found, the agreement which ties between seller and buyer of this sale is executed. When both parties have agreed on the price of fish in the lebung, then the buyer will give the amount of money that has been agreed from the auction process to the seller of fish in the lebung. The payment is done by cash while it is still possible when a buyer only delivers part of

${ }^{3}$ Based on interview with Mr. Asmadi, a buyer at Seri Kembang I village. 
the price and settles the remaining in the next days after catching and selling all the fishes. Sellers and buyers of the fish will be both happy and accept the risk of the sale. In case in the following days it is found that the value of fishes is more then the sale price, then the seller is not allowed to make complaint. The opposite is true, when the value of fishes is less then the sale price, buyer is not allowed to make complaint. However, some buyers or sellers are disappointed from the lose they get.

The auction is done during the dry season because the volume of water will decrease so that the fishes can be seen clearer and facilitate the process of fish catching. The winner of auction has right to utilize the lebung until the next rainy season comes. ${ }^{4}$ Another case is when the lebung runs of fishes, the winner of auction may return it back directly to the seller. ${ }^{5}$

\section{DISCUSSION AND RESULT}

\section{Analysis on The Conditions of Sale}

The practice of fish sale inside lebung using auction model in Seri Kembang I village has to be examined thoroughly using the parameter on the theoretical part above.

a. Condition for contracting parties

For what we observe, both parties involved in this practice are sane, mumayyiz and has freedom on what they do.

b. Conditions for subject matter

There are five elements we have to focus in this parameter as it is mentioned at theoretical part. We conclude that the first until fifth element are fulfilled, meaning the practice confirms its theoretical requirements. Nevertheless, the

${ }^{4}$ Based on interview with Mr. Kurai, a buyer from Seri Kembang II village.

${ }^{5}$ Based on interview with Mr. Asmadi, a buyer at Seri Kembang I village. 
fourth element of this condition which is deliverability of the subject matter need be to discussed further. This is because the actual subject matter of this sale is the fish which still remains inside lebung cannot be delivered during the time of contract.

The fifth element, that is subject matter must be known to both parties, needs even more inquiries. The subject matter of this sale is the fish inside lebung. From our opinion, both seller and buyer has made their best attempt to predict the fish inside lebung. The attempts include description of the fish and water organism by seller, and five steps done by the buyer himself: catching the fish using net, observation of fishes which appear on the top level of water, measuring the width and length of lebung, walking around lebung, and using past experiences. Thus, it represents the very close estimation of fish inside lebung. In a simple word, the fifth element of this condition has been fulfilled.

c. Conditions for the price

The seller set the standard price for the beginning of auction to potential buyers. In the other side, buyer has their cash ready except for cases when the buyer wants to pay part of the price within clear and agreed date. Thus, this sale fulfills the condition for the price. In addition, the exchanged item here is not type or ribawi item which makes the rule of riba does not apply here.

d. Conditions of statement of contract

From what we observe on both seller and buyer, the auction is done in the same place (majlis), that is around the lebung. Both parties are also willing to accept the consequence on such sale (have consent). The offer and acceptance is 
done by oral agreement which also constitutes firmness of the statement. We conclude that the practice confirms all condition along with all its elements.

\begin{tabular}{clc}
\hline No & \multicolumn{1}{c}{ Standard } & Conformity \\
\hline $1 \quad$ Conditions of contracting parties & $\checkmark$ \\
& $\checkmark$ Sane ('aqil) & $\checkmark$ \\
& $\checkmark$ Mumayyiz & \\
$2 \quad$ Conditions of the subject matter & $\checkmark$ \\
& $\checkmark$ Purity of subject matter & $\checkmark$ \\
& $\checkmark$ Usefulness of subject matter & $\checkmark$ \\
& $\checkmark$ Possession over subject matter & $\checkmark$ \\
& $\checkmark$ Deliverability of subject matter & \\
& $\checkmark$ Subject matter must be known to both parties \\
& Conditions of the price & $\checkmark$ \\
& $\checkmark$ Clarity of the price & $\checkmark$ \\
& $\checkmark$ Deliverability of the price & $\checkmark$ \\
& $\checkmark$ Free from riba & \\
4 & Conditions of statement of contract & $\checkmark$ \\
& $\checkmark$ Clarity of the statement & $\checkmark$ \\
& $\checkmark$ Conformity of the statement & $\checkmark$ \\
& $\checkmark$ Connection of acceptance with offer & \\
& $\checkmark$ Firmness of both statement &
\end{tabular}

For the conditions on the auction, the practice fulfills all the requirements. This is because the auction itself is type of the sale. Thus, the discussion on the parameters of sale can be said covers the inquiry on auction in particular. So far, the practice of fish sale within lebung only has one thing that seems to deviate from the parameter, that is the deliverability of the subject matter. This is because the fishes are inside the water during the process of transaction. 


\section{Garar Analysis}

Every human being must face uncertainty in their life whether in social or business activity. Islam does not deny this reality and does not prohibit human from facing such risk of uncertainty in life (Iqbal, 2005). Exercising garar is prohibited, but it does not mean Islam prohibits facing the risk. In fact, dealing with risk has been acknowledged and supported by Islam (Warde, 2009). Thus we can find an Islamic legal maxim saying that any profit must come with its necessary risk which implies riskless profit is almost impossible. From this point, we can understand why riba is completely prohibited while garar has the allowed and prohibited type.

The practice of fish sale inside lebung at Seri Kembang I village seems to contain garar. Nevertheless, there must be analysis as the level of garar is excessive enough to conclude that the contract is prohibited or vice versa. The analysis of garar uses the parameter mentioned at the theoretical part above.

1. The garar is excessive in a contract.

From the observation on the practice at the field, people do not consider this contract as bad or containing excessive garar. Instead, it has been mutually understood. In addition, it has been the practice of the local government marga from past decades until today that still exercised yearly. Garar meant in this sale cannot be avoided on the quantity, quality and variety of the fishes and other water organism inside lebung. However, attempts to minimize the element of garar so that it does not reach the level of excessive garar have been done by all parties. This is to ensure that no undesirable outcome after the auction by the dispute between the parties. In a simple word the prohibited garar is that leads into dispute 
while the allowed one is the garar which cannot be avoided yet does not lead into dispute. The practice here is the type of the latter.

2. The garar happens in the core contract.

From the observation on the practice at the field, the main object of this sale is the fish inside lebung. According to authors' opinion, it is in fact the fish becomes the subject matter here since the ultimate purpose of this exercise is to own the fish inside lebung, not the lebung itself. The lebung remains under the ownership of seller. Thus, the rule of garar applies here. This is different if the buyer buys a part of land which contains lebung with fishes inside it. The land in this sale becomes the main subject matter while the lebung and fishes are complementary. In a simple word, any rule regarding garar applies in the sale of fish inside lebung practiced at Seri Kembang village I.

3. There is no authentic need (hajat syar' $i$ ) for the contract. From the observation on the practice at the field, the garar character within the sale cannot be denied while such transaction is important among the society, especially for sellers and buyers of fish. However, it is need to be discussed further whether there is no any more appropriate halal way to fulfill the need of citizen. In authors' opinion, there are still some ways to avoid this garar that is the owner of the lebung itself who manages and catch the fish to sell to the market. Another way is by letting the buyer himself to catch all the fishes within lebung and the price is decided later based on the quantity and quality of the fishes. For a better offer, the price must be different from the market price. The agreement of using different price from market can be done prior to 
catching the fish to ensure the buyer.

The conclusion of our research in this point is that the sale is importantly needed by buyer and seller of fish sale inside lebung. However, we find no authentic need so that it can support the practice of garar in this transaction since there are some other permissible ways which are more appropriate for both buyer and seller. In case that the practice is prohibited, it does not necessarily make people suffer. In a simple word, this practice does not conform the third parameter of garar.

4. The garar happens in commercial contract

Form the observation on the practice at the field, the subject matter of this transaction is the fish inside lebung. It means that such transaction is type of commercial contract and thus the rule of garar applies here.

From all garar analysis elaborated above, we can see that the garar does exist in this transaction. It comes from the first point even though both buyer and seller make their best attempt to minimize the garar. However, when it comes to the analysis of garar in point two until four, the existence of garar cannot be neglected anymore which result the prohibition of this contract from Islamic perspective.

\begin{tabular}{cll}
\hline No & \multicolumn{1}{c}{ Standard } & Violation \\
\hline 1 & The garar is excessive in a contract & \\
2 & The garar happens in the core contract & \\
3 & No authentic need for the contract & \\
4 & The garar happens in commercial contract & \\
\hline
\end{tabular}

From the two tables which summary the analysis, we can see that all of the pillars are fulfilled, while there is one of the 
condition remains in question. The deliverability of the subject matter is not yet fulfilled since the fishes are still inside lebung during the process of contract. Selling commodity which cannot be delivered is kind of gambling and speculation since no one knows whether the fish really can be caught or not and thus such sale is invalid (Sabiq, 2011). This practice resembles the prohibition from hadith which states that it is not allowed to sell milk inside the stocks and an explicit hadith for prohibition of selling fish inside water which narrated by Ahmad, "Do not sell fish inside water as it contains garar."

Also as we know that selling things which its quantity and quality are not known is type of seeking profit by the way of speculation which potentially leads into dispute within society. The hadith above has the basis for garar analysis summarized at the table above. Three out of four criteria of garar is fulfilled which confirms the garar element inside this contract. The analysis leads us to conclude that the practice of fish sale inside lebung at Seri Kembang I village is prohibited.

The social benefit of this prohibition is not to take others wealth without their proper consent. Apart from that, the prohibition closes the possibility of conflict and dispute that may arise from the result of injustice and harmed part of the transaction. Of course, it also keeps the wealth to be under His blessing

\section{CONCLUSION AND SUGGESTION}

Fish sale inside lebung is a common practice in South Sumater. The fish sale inside lebung is done through some steps. First, the buyers come to the owner to ask questions related to the subject matter of the sale followed by the description by the 
seller. Both parties then check together the subject matter, that is the fish inside lebung. Only then the fish will be sold through auction model to the buyers commenced by the seller setting standard price at the beginning of auction.

From the Islamic perspective on the practice of fish sale in lebung through auction model, there is one condition that has not been fulfilled that is the non-deliverability of the subject matter, makes this transaction cannot be said as valid. Thus, the nonfulfillment of such condition resulting in this sale contains the elements of garar and gambling which is prohibited in Islam. Apart from it, both buyer and seller do not know exactly the quality and quantity of the fish that will be sold. Finally, this research reaches the conclusion that the practice observed is prohibited.

We also want to provide some suggestion that hopefully can be useful

- First of all, for all buyers and sellers have to be more careful in doing transactions so as to conform with shariah requirements, including its pillar, conditions and free from any prohibited elements. This is to ensure that all sale and purchase will always be blessed by Allah.

- In our opinion, there is still another way can be done to avoid the element of garar in this sale. The owner himself who manages the lebung and catch the fishes, continued by selling it to the market or directly to the society. Another way is by selling the fish inside lebung to the usual buyer yet the process of catching done by the buyer himself. The price that buyer has to pay is determined by the actual quality and quantity of fishes caught. It also has to be noted that prior to the catching of fishes by buyer, there has to be an agreement 
that the must be different from market price since the buyer puts his effort to catch the fish. This way of conducting sale is more appropriate and the justice for both parties can insured.

\section{REFERENCE}

Afandi, M.Y. (2009) Fiqh muamalah dan implementasinya dalam lembaga keuangan syari'ah: dilengkapi dengan kamus istilah perbankan syariah. Yogyakarta: Logung Pustaka.

Arfan, A. (2013) 99 kaidah fiqh muamalah kulliyah: Tipologi dan penerapannya dalam ekonomi Islam dan perbankan syariah.Malang: UIN Maliki Press.

Ath-Thayyar, A. M. (2015) 'Al-Fiqh Al-Muyassar' in Khairi, M. (Translated) Enskilopedi Fiqih Muamalah dalam Pandangan 4 Mazhab. Yogyakarta: Maktabah Al-Hanif.

Azhim, A. (2011) 'Al-Wajiz Fi Fiqhis Sunnah Wal Kitabil'Aziz' in Jalil M. A. (translated) Al-Wajiz ensiklopedi fikih Islam dalam Al-Qur'an dan As-Sunnah Ash-Shahihah. Jakarta: Pustaka As-Sunnah.

Hasan, M.A. (2003) Berbagai macam transaksi dalam Islam (fiqh muamalat). Jakarta: Raja Grafindo Persada.

Harun (2015) Islam dan ipteks. Surakarta: LPIK UMS.

Iqbal, M. (2005) Asuransi Umum Syariah dalam Praktik Upaya Menghilangkan Garar, Maisir, dan Riba. Jakarta: Gema Insani

Karim, A.A., (2015) Riba garar dan kaidah-kaidah ekonomi syariah analisis fikih dan ekonomi. Jakarta: PT. Raja Grafindo Persada.

Na'imah, I., (2012) Tinjauan Hukum Islam Terhadap Praktek 
Jual Beli Ikan dengan Sistem Tebasan di Desa Sekaran Kecamatan Sekaran Kabupaten Lamongan. Skripsi, Fakultas Syari'ah dan Hukum UIN Sunan Kalijaga Yogyakarta.

Nasehudin, T. S., \& Gozali, N. (2012) Metode Penelitian Kuantitatif. Bandung: Pustaka Setia.

Nurudin, (2009) Tinjauan Hukum Islam Terhadap Praktik Jual Beli Ikan Dengan Sistem Pancingan (Studi Kasus di Dusun Ringin Sari Maguwwoharjo Kecamatan Depok Kabupaten Sleman). Skripsi, Fakultas Syari'ah dan Hukum UIN Sunan Kalijaga Yogyakarta.

Rusyd I. (1992) Bidayatul Mujtahid vol. II. Lebanon: Beirut.

Sabiq, M. S. (2011) ‘Fiqhus Sunnah’ in Muhayan M. (translated) Fiqih Sunnah 5. Jakarta: Pena Studi Aksara.

Satori, D. A. Aan komariah. (2012) Metode Penelitian Kualitatif. Bandung: Alfabeta.

Riduwan, M. B. A. (2006) Belajar Mudah Penelitian Untuk Guru-Karyawan dan Peneliti Pemula. Bandung: Alfabeta Tarmizi, E., (2017) Harta Haram Muamalat Kontemporer. Bogor: PT. Berkat Mulia Insani.

Warde, I (2009) Islamic Finance Keuangan Islam dalam Perekonomian Global. Yogyakarta: Pustaka Belajar.

Yudianto, M., 2015. Tinjauan Hukum Islam Terhadap PraktekAkad Jual Beli Ikan Nelayan (Studi Kasus Di Desa Pangkalan Kecamatan Sluke Kabupaten Rembang). Sskripsi, Fakultas Agama Islam Universitas Muhammadiyah Surakarta. 